Volume 9 | Issue 4

০o

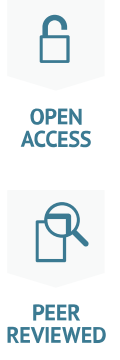

\title{
Platform developmentalism: leveraging platform innovation for national development in Latin America
}

\author{
Katherine Reilly Simon Fraser University kreilly@sfu.ca \\ DOI: https://doi.org/10.14763/2020.4.1538
}

Published: 22 December 2020

Received: 8 November 2019 Accepted: 5 February 2020

Funding: This paper was written with the support of the Social Sciences and Humanities Research Council (SSHRC) of Canada.

Competing Interests: The author has declared that no competing interests exist that have influenced the text.

Licence: This is an open-access article distributed under the terms of the Creative Commons Attribution 3.0 License (Germany) which permits unrestricted use, distribution, and reproduction in any medium, provided the original work is properly cited. https://creativecommons.org/licenses/by/3.0/de/deed.en

Copyright remains with the author(s).

Citation: Reilly, K. (2020). Platform developmentalism: leveraging platform innovation for national development in Latin America. Internet Policy Review, 9(4). https://doi.org/ 10.14763/2020.4.1538

Keywords: Platform economy, Policy disruption, Developmentalism, Latin America, Platforms

\begin{abstract}
Recently, development scholars have begun to study the platform economy. In Latin America, platformisation has resulted in the widespread reorganisation of business practices across many sectors, with important implications for incumbent industries, labour and social processes. These changes raise questions about the potential contributions of platformisation to national economic health and social welfare. This paper argues that the link between platformisation and development can be studied from a developmental state point of view. Specifically, in Latin America, the disruptions caused by platform innovations create policy windows that could result in platform developmental policy innovations, however, developmental policy-making is constrained by the structural characteristics of Latin American economies. Taking this into consideration, the paper positions Biber et al.'s (2017) model of policy disruption, and Fairfield's (2015) model of policy influence as tools to critically assess platform policymaking from a developmentalist point of view. This approach is illustrated through a survey and discussion of policy disruptions caused by platformisation in the transportation, lodging and fintech sectors of Chile, Colombia, Mexico and Peru. The discussion surfaces specific challenges for platform developmentalism related to policy autonomy and capture, societal mobilisation of data and other resources, and state-market collaborations. The paper concludes by positioning the 'platform society' as a normative goal and offers an agenda to advance it through comparative research of platform policymaking.
\end{abstract}




\section{Introduction}

In the last few years, international development scholars have explored the rise of platform businesses in developing countries (Galo, 2016; Hira \& Reilly, 2017; Koskinen et al., 2018). By platform businesses, I mean multi-sided platforms (Hagiu \& Wright, 2011) that broker logistics (Reilly, 2017) between actors within a marketplace through digital means (Kenney \& Zysman, 2016; Srnicek, 2017). The adoption of platform models has resulted in the widespread reorganisation of business practices across many sectors, with important implications for incumbent industries, labour, and social processes. Within this new field of study, theories about the relationship between the process of platformisation and social change or development outcomes are only just beginning to emerge. Among these, Ezeomah and Duncombe (2019) suggest focusing on how platformisation of business processes reshapes the efficiency or effectiveness of value chains, Koskinen, Bonina, and Eaton (2018) look at the implications for labour, Artopoulos (2019) asks whether ecommerce platforms potentiate small and medium enterprises, and, IT for Change offers a global social justice framework (Gurumurthy, 2018).

In this paper, I consider the policy conditions that shape the developmental potential of the platform economy from a developmental state point of view (Johnson, 1982; Evans, 1995; Haggard, 2018), and I explore this approach using case material from Latin America. Unlike neoliberal regulatory approaches which use policy to regulate a balance between competing interests (Levi-Faur, 2005; Osborne \& Gaebler, 1992; Jayasuriya, 2001), developmentalism suggests that states can and should establish complementary social and economic goals for the nation, and then govern with corporate and social actors to achieve these goals in ways that produce both economic growth and social benefits. The approach to platform policymaking offered here differs fundamentally from the regulatory recommendations offered by the G20 (Schwarzer et al., 2019) and the Inter-American Development Bank (2017) for the platform economy.

I start by briefly reviewing the idea of the developmental state and relating it to the notion of platformisation. I then consider the structural barriers facing stateled developmental interventions in the Latin American context. Taking this into consideration, I offer a set of concepts for comparative analysis of the politics that surround policy-making for developmental governance. Finally, I demonstrate the relevance of these concepts by exploring instances of policy struggle resulting from platform technology disruptions in the transportation, lodging and fintech sectors in Chile, Colombia, Mexico and Peru. These cases offer further insights into the nature of platform developmentalism and raise key issues that policymakers 
would need to keep in mind when attempting to leverage platformisation to achieve national development objectives. In the conclusions, I draw from these illustrations to suggest some specific areas for future research based on this approach.

\section{The developmental state and Latin America}

The extensive literature on the developmental state has been detailed in focused literature reviews (Bagchi, 2000; Routley, 2012). My efforts to apply the concept to Latin America, and also to post-industrial economies, position me outside of the purist camp which views the developmental state as a specific formation that occurred in Asia during the post-war period. Instead, I leverage the concept as a framework for socially oriented policy-making (Singh \& Ovadia, 2018).

With this in mind, broadly speaking, developmentalism studies the role of the state in fostering economic growth that can be leveraged to generate social benefits. Early works in this field emphasised the role of industrial policy in driving rapid transformations in Asia's late industrialising countries (Johnson, 1982; Evans, 1995). The developmental state literature offered a contrasting narrative to the neoliberal, small state regulatory approach promoted by the Washington Consensus, ${ }^{1}$ both by highlighting the positive potential of a strong, interventionist state, and by prioritising shared and equitable growth (Pérez Caldentey, 2008). These 'strong states' had sufficient bureaucratic expertise, as well as autonomy from social and economic pressures (Evans, 1995), to solve coordination problems that undermine economic growth (Amsden, 1989; Haggard, 2018).

In terms of social policy, early work in the genre focused on absorption of surplus labour and upskilling the workforce. Pérez Calendey (2008) argues that while the Washington Consensus contemplates state provision of education, healthcare and pensions to support workers, it ignores the developmentalist idea that "growth is a precondition for the improvement of welfare" (p. 49). And, as Bagchi (2000) argues "increases in inequality tend to depress income growth [...] Thus without a drastic change in policies leading to increased construction of social and physical capital, these developing countries will remain doomed to poverty and social disarray" (pp. 435-6). So, recent works have sought to recover and expand the social role of state economic management, taking into consideration the constraints posed by globalisation. In order to reduce social exclusion, the social developmental state should

1. The Washington Consensus refers to a set of free-market policies promoted by the World Bank, International Monetary Fund, and the Inter-American Development Bank in response to economic crises in developing countries sparked by the debt crisis of the 1980 s. 
therefore strive to engage with global markets in productive ways while also mitigating their negative impacts on society (Sandbrook et al., 2007, pp. 232-4).

Latin American countries have a notable history of industrial policy, and several countries in the region took up new forms of economic management in the early 2000s as part of the region's Pink Tide ${ }^{2}$ and post-Washington Consensus moment (Bresser-Pereira \& Theuer, 2012). However, as Schneider (1999) argues, while Latin American states often have developmental objectives, these plans take place in the context of personalistic bureaucratic appointments, powerful business interests, and social exclusion from decision-making. These factors undermine the state's best developmentalist intentions, and raise the question of whether Latin America offers examples of developmental states or merely developmental policies.

In this context, rather than succumb to debates over ideal types, the developmental state literature can be seen as a benchmark for governmental efforts to move in the direction of greater state intervention in economic management with a view to advancing social policy. This implies studying regulatory projects that challenge established policy approaches and entrenched interests. The technological innovations offered by platformisation may cause just such a disruption, and can therefore be studied as moments of potential for social change.

\section{Platform developmentalism}

A developmental approach aligns with van Dijck et al.'s (2018) argument that "The responsibility for a balanced platform society rests [...] with all actors involved in its construction [...] [but] supranational, national, and local governments have a special responsibility in this regard" (p. 6). However despite devoting a chapter to governance, van Dijck et al. leave us with little concrete foundation for policy research, observing expansively in their concluding paragraph that: "who governs the platform society and how it should be governed based on what values is complex and multifaceted" (p. 163). As one reviewer from the Indian Journal of Human Development observed "The writers though do not offer a clear solution, successfully elaborate and analyse the prevailing situation" (Shipra, 2019, p. 238). Meanwhile Miconi (2020) critiques van Dijck et al. (2018) for not taking a clear position on the exploitative dynamics of platformisation noting that its analysis ought to "lead to a more radical conclusion about the nature of platform society, with structure fatally becoming more relevant than agency" (p. 792).

2. The Pink Tide ('Ola Rosada') describes a wave of left-wing electoral victories that took place in Latin America from 1998-2010. 
Some recent works have begun to suggest developmental approaches to platform regulation. Since platforms are themselves innovations, and platformisation also requires business and technological innovations to support uptake, innovation policy is one part of the equation. Katz argues that Latin America's governments need to find new ways to resolve inefficiencies in private incubation of digital companies, since these offer high returns on investment: "Industrial policies and technologies are central to effectively reducing gaps in the digital sector so that their positive effect on growth and productivity can manifest its full potential" (Katz, 2015, p. XIX; see also OECD, 2016).

This is closely related to regulation for value chain innovations in the platform economy. Platform business models offer the potential to enhance supply chain efficiency in ways that drive economic growth (Ezeomah \& Duncombe, 2019). However, as Artoplolous et al. (2019) point out, the state must create the conditions that enable small and medium enterprises to participate in newly platformised value chains by ensuring sufficient connectivity, but more importantly by "redefining the architecture of domestic commerce given the possibilities offered by ecommerce" (p. 279).

This raises questions about how to regulate the global data value chain across the base data layer, the cloud computing layer, the intelligence layer, and the consumer-facing intelligence services layer (Singh, 2020) so that countries are able to harness big data and artificial intelligence to support developmental objectives in the platform economy (Gurumurthy et al., 2020). Such regulation might enhance or defend national information systems so that they are available to support the above mentioned processes of innovation and supply chain management. This might mean nationalising certain parts of the data supply chain (data sovereignty), legislating data property rights and the benefits that flow from them, or supporting the development of domestic capacity.

Thirdly, platformisation is widely acknowledged to undermine labour standards (Graham et al., 2017), but despite this, several developing country governments have looked to the gig economy as a potential means for labour absorption (ibid, p. 138). Socially-minded labour market regulations for the platform economy would drive labour absorption across a spectrum of skill sets within the platform economy, and also devise a means to upskill the market so that workers can transition to higher paying jobs over time (Parthasarathy \& Matilal, 2019). Fostering national data and information systems is one way that governments can upskill the platform economy labour market. 
While they offer a clear vision of what platform developmentalism might imply, these works do not always draw a clear line from economic policy to social gains. For example, Katz (2015) suggests that the growth of the digital sector could benefit people by giving them better access to basic services, better access to the political process, by reducing prices, and by increasing salaries (p. 131), but the suggested gains fall short of upward mobility or redistribution of wealth. Even platform economy labour policy tends to focus on ameliorating the worst impacts of labour outsourcing rather than proposing developmental alternatives.

What would it mean to adopt a fundamentally developmentalist approach to platform policy making? We can arrive at a better understanding by contrasting regulatory and developmental approaches to regulating personal data, which is a fundamental factor of production for the platform economy (Srnicek, 2017, p. 23). In Latin America personal data regulations take a regulatory approach, which, much like the General Data Protection Regulation of the European Union, seeks to strike a balance between a personal need for privacy, and a corporate need for access to personal data (Rodriguez \& Alimonti, 2020). The question driving this type of policy is thus What is the right balance between the privacy rights of individuals and the ability of firms to innovate and grow? The resulting regulatory frameworks are arm's length and business-centric.

Since a developmental state aims to resolve the coordination problems that undermine a nation's transition towards an inclusive equilibrium between business and social interests, then the question driving policy-making would instead be What is the best way for the community to invest its data resources or mobilise platformization? This would imply situating data and information systems at the centre of national development efforts and engaging in hands-on policies that advance the stewardship of data resources and information systems at a national level. In distinction to the view put forward by the Data Commons Manifesto (tecnopolítica, 2020), in this case a data commons therefore implies governance of the tensions between communal-individual data, open-owned data or data extractivism-data social responsibility with a view to achieving developmental ends. Policy would work to cultivate data systems, enforce data incentive mechanisms, and produce strategic data sets that support the resolution of economic and social coordination problems through platformisation. One of the main advantages of this approach is that it situates the social production of platforms at the centre of industrial policymaking for the achievement of developmental objectives within a particular local context. 


\section{The Latin American context}

Advancing policy of this kind would require the buy-in of both public and private sector actors, but in Latin America this is a difficult proposition. As a result of the historical trajectories which have given rise to the Latin American expression of capitalism:

The structural situation in the region confirms that the institutional trajectory of inequality prevails as a product of the reproduction of benefits concentrated in elite power compacts and extended social habits and support rentier comportment and favor informality, with negative consequences for the distribution of income and the possibilities that this might create. (Hernández López, 2017, n.p.).

In this context, economic policy is heavily guided by multinational corporations and diversified business groups that benefit from the continued presence of low skill labour to extract a profit (Cimoli \& Rovira, 2008; Schneider, 2008, 2009, 2013; Serna \& Bottinelli, 2019; Egan, 2010). There is every suggestion that platform enterprises will align with this logic given the lean business practices (Srnicek, 2017, p. 39) that lie at the heart of platform business models.

Because business conglomeration and low labour costs are effective strategies to mitigate business risk and generate profits, both domestic and multinational firms work to sustain these strategies through political influence. As Schneider explains "political systems and practices in Latin America are remarkably accommodating for business interests, especially narrow or individual interests of big business" (Schneider, 2013, p. 148). Business groups that have emerged out of the family holdings of bygone eras are able to influence politics due to key structural advantages, including money, growth through acquisitions, and, with growing transnationalisation, the threat of shifting their investments abroad (López García, 2017). Thus, the region's political systems tend to favour insiders who press governments to sustain economic institutions that maintain long-standing relations between corporations and labour.

These structural conditions make it very difficult for governments in the region to intervene in the economy to promote economic growth, let alone to pursue social agendas. One effect of this are low rates of innovation in Latin America, which undermine economic development (Castillo et al., 2016, p. 21). ${ }^{3}$ For example, Sauce- 
do et al. (2016) draw a correlation between the structural factors described above as they manifest in Argentina, Brazil and Mexico, and low levels of innovation in these three countries, in comparison to analogous economies with different structural conditions in other parts of the world.

The case of Chile offers a concrete example of how these dynamics manifest in policy processes throughout the region. In this country, there are several large firms that combine resource extraction with service offerings, such as Matte (forestry, mining, energy, and banking), Angelini (forestry, mining, fishery, and gas) or Luksic (mining, energy, beverages, and banking). As a result, despite Chile's strong GDP, $65 \%$ of its exports are primary materials, and $80 \%$ of those are copper, so the economy is undiversified, and products exhibit low complexity (Guzmán, 2016). These firms could invest in developing new markets, which would in turn create new and higher paid jobs, but the structure of their businesses does not incentivise the pursuit of new innovations. Meanwhile, past policies undermined innovation. For example, the Taxable Utilities Fund (FUT), which was created in 1986, allowed companies to postpone tax payments when they reinvested in utilities. It resulted in an accumulation of US\$200 billion over the course of a decade, however in that same period private R\&D was only around US\$300 thousand per year (Jara Román, 2019).

Since 2000, Chilean governments have pursued policies to incentivise investment in innovation, but their efforts have been blocked by business elites. As Bril-Mascarenhas and Madariaga (2017) explain, the Lagos government created the National Council for Innovation and Competitiveness (CNIC) in 2005 to manage an Innovation for Competitiveness Fund (FIC) with the aim of leveraging taxes from mining wealth to drive economic diversification. The initiative was actively opposed by business interests who used legislative influence to water down the relevant tax law, and took control of the board of the CNIC to shape its policy interventions. Once pro-business leader Piñera came to power in 2014 "the CNIC was de facto depleted of its original purpose" and its agenda was modified to "fostering a "culture of innovation' among individual entrepreneurs rather than strengthening the policy and institutional environment for firms to upgrade their productive capacities" (Bril-Mascarenhas \& Madariaga, 2017, n.p.). They conclude that "we cannot understand why executive-branch leaders in post-authoritarian Chile were not able to deviate from a policy path originated in the mid-1970s without considering how big business used its leverage to circumscribe the set of 'viable' industrial policy alternatives and bias policy making toward its preferred small-state poli- 
cies" (n.p.).

This case is emblematic of the relationship between business interests and the state throughout Latin America. It shows that Latin American regulators do pursue developmental policies in an effort to drive growth and social change, however, they face strong structural challenges to the effective realisation of these plans even when they might advance economic interests.

This is a pattern that repeats throughout the region, and is evident in all four of the countries considered as case examples below: Chile, Colombia, Mexico, and Peru. For example, in Colombia, elites focused on advancing transnational capitalism have captured local policy-making processes to the detriment of fundamental development of the local supply chain, undermining the productivity of local companies (Franz, 2018). In their in-depth work on the political economy of Peru, Crabtree and Durand (2017) show that private sector co-optation of state power has become the norm, and is used to prevent state intervention in the marketplace. Finally, Ondetti explains that Mexico has the lightest tax burden in Latin America as a result of "the resistance of an exceptionally politically mobilized economic elite, which has resulted in the defeat or dilution of repeated attempts at reform" (2017, p. 47). Indeed, in his first speech as President of Mexico in 2018, left-leaning leader López-Obrador announced that under his mandate, "The government will no longer be a committee at the service of a rapacious minority" of "rapacious elites" nor would it be a "simple facilitator of pillaging, as it has been" (López-Obrador, 2018).

\section{Platform developmentalism and policy disruption in Latin America}

Under these conditions, the ability to pass developmental policy-making depends on the relationship between the state and economic actors. Hegemonic coalitions differ between countries, and this explains historical differences in the organisation of capitalism and development outcomes between countries. Brazil has stateled development of internal markets; in Mexico, liberal capitalism focuses on export markets; and, in Chile, state regulation of capitalism drives export markets. Each of these models arise according to how hegemonic coalitions have guided capitalism within each country, and how business interests have adapted to these realities (Bizberg \& Théret, 2012; Gaitán \& Boschi, 2015). This points to the importance of comparative analysis for studying the relationship between state and market in platform policymaking and the resulting platform economy (Sheahan, 2002; Boschi, 2011). 
Biber et al. (2017) provide a useful framework for comparative study of platform policy-making. They argue that not all technological disruptions require policy reform, but in the platform economy, technological disruptions frequently cause collateral policy disruptions, which in turn give rise to policy windows that could lead to new regulatory approaches (p. 1580). When faced with such a policy disruption, they say, regulators should be neutral between different business interests, while taking into consideration the health, safety, environmental, privacy or distributional consequences of business activities (p. 1608). If health and safety outweigh neutrality between incumbents and newcomers, then policymakers would be justified in blocking the newcomer to the advantage of the incumbent. But if innovation benefits outweigh the need to be neutral, policymakers would be justified in favouring the newcomer to the detriment of the incumbent. Finally, they model four types of policy disruption: end runs, exemptions, gaps or solutions (p. 1565). In an end run, innovators argue that existing policy does not apply to them because their business is fundamentally new. Exemptions are cases in which innovators are exploiting exceptions in existing policies. Gaps cover cases in which innovators raise entirely new policy concerns, and there is no applicable policy. Finally, solutions are cases in which the innovator offers better social welfare outcomes, but faces barriers under existing regulations.

Layering-in a developmentalist logic, if innovations serve to unlock structural barriers to development then they should be pursued, and if they reinforce those barriers they might well be avoided. In particular, applying a platform developmentalist logic, the state would favour or even incentivise innovations that advance the stewardship of data resources and the creation of information systems in ways that promote balanced growth. If national development objectives outweigh narrow business interests, governments would be justified in crafting regulatory frameworks that prioritise the achievement of development gains. In the case of end runs, exemptions or gaps, a regulator would evaluate the economic and social potential of the new model, and either block the innovation if it undermines developmental gains, or introduce new regulations to support the innovation if it can be leveraged to advance them. In the case of solutions the regulator could either give the innovators a free pass (no new policy), or introduce new regulatory structures that better enable people to leverage these new benefits.

If policy resulting from platform disruptions falls outside of these frameworks, then we can surmise that either there has been a failure of governance, or the process has been co-opted by special interests. According to Fairfield (2015), these special interests can be expressed through instrumental power, structural power, 
electoral influence and social forces. The first two are the domain of businesses. Instrumental power is expressed through "favorable relationships with policymakers that enhance access and create bias in favor of business interests" (ibid., p. 420). Structural power is the ability of businesses to mobilise investment decisions to influence state decisions. Electoral influence is the pressure that elected officials feel to serve the public, as when they feel pressure to support Uber because it is well liked by users. Lastly, people affected by technological innovations can create pressure through popular mobilisation, as when taxi unions have protested against the introduction of Uber. The latter two forms of pressure could in theory legitimise a neutral position by policymakers, however these forces can be co-opted by business interests as well. In particular, the ability of platform businesses to mobilise electoral power has been well documented by observers around the world (Gillespie, 2010) and in Latin America (Torres Castro, 2016).

\section{Analysis of policy disruptions}

By applying Biber et al.s framework and Fairfield's analysis of special interests, it is possible to explore the dynamics shaping the emergence of platform policies in Latin America, and consider whether platform developmentalism is leveraging these new technological innovations to advance economic and social goals in the region. Case material drawn from a review of policymaking in the transportation, lodging and fintech sectors of Chile, Colombia, Mexico, and Peru demonstrates how the ideas presented above can be used to analyse platform policymaking from a developmental point of view. These accounts are meant to be illustrative of the potential of the framework, rather than comprehensive in their analysis. They reveal specific themes of importance to developmental policy-making in the platform space: policy autonomy and capture in the case of transportation policy, how society values and leverages resources in the case of lodging, and state-market collaborations in the case of fintech. Based on these presentations, the conclusions offer possible avenues for future research that could explore platform developmentalism in greater specificity and with comparative rigour.

These four countries were selected as sources of case material to conduct an initial exploration of the model presented above because of their advanced uptake of platformisation, and also because they are particularly strong examples of the structural dynamics discussed above. They rank among the top six Latin American countries for ICT sector value added as a share of GDP 2010-2017 according to UNCTAD (2019, p. 74); among the top six Latin American countries in terms of the economic impact of digitalisation 2005-2013 (Katz, 2015, p. 167); among the top 
six Latin American countries in terms of job creation from digitisation (2005-2013) (ibid, p. 170), and among the top six in terms of financing for digital innovation (ibid, p. 282). Brazil, Argentina and Costa Rica also figure prominently in these classifications, however, Gaitán and Boschi (2015) argue that in Chile, Colombia, Mexico and Peru, government plays only a "subsidiary role" in terms of regulating economic activity (p. 180) in contrast to other Latin American states where governments have pursued more interventionist roles such as Argentina and Brazil, or Bolivia, Ecuador and Venezuela. Costa Rica, for its part, is well known as an exceptional case in Latin America (Sandbrook et al., 2007). The industries were selected because, according to a study conducted by Barros for the Government of Chile, they have been the most affected by platform disruption in Latin America (Barros, 2018).

\section{Transportation: policy autonomy and transnational policy capture}

The contrast between taxi regulation in Chile and Peru offers insights into the autonomy and capacity of policymakers in the two countries where platform policymaking is concerned. In July 2019, Chile's Senate approved a new law to regulate ride-hailing (Cámara de Diputados de Chile, 2018). The law defines "Transportation Application Companies" as offering a service that allows a user to contract a driver for the purposes of moving from one place to another. Companies must be legally constituted in the country, registered as a tax paying entity, and offer civil and life insurance for both drivers and passengers. They must also provide a means to receive complaints, which implies having local staff in the country. The law creates a public registry with information about companies, drivers and vehicles. Drivers must have a professional taxi licence, and their vehicles must meet minimal technical, safety and signage requirements.

Meanwhile, a legal project with broad similarities was approved by the Congress of Peru in 2018 (Congreso de la República de Perú, 2016). It aimed to regulate entities that administer the digital intermediation of transportation services that allow passengers to access a paid transportation service. Peru's legal project focused on consumer protection. It contemplated a registry, required companies to constitute themselves legally within the country, and to have "at least one administrative officer in the country, and a central telephone line with 24-hour a day client service" (Article 4). The project includes basic requirements around car insurance and licencing, but is less comprehensive in terms of taxation, insurance, public registries, licencing and safety than the Chilean law.

In Chile, the traditional taxi sector has been vocal in defending its position within 
the marketplace, and has demanded that regulators step up to protect their standing (Díaz, 2019). Chile's taxi sector took the form of unions with invested privileges, so both drivers and the companies they work for stood to lose through the introduction of ride-hailing apps. In Peru, in contrast, taxis have a long history of operating illegally, and efforts to regulate the sector have faced continual challenges (Cohen, 1987; Pashley \& Hidalgo López, 2014). Uber's arrival to Peru did provoke protests in September 2016, at which drivers argued that the $30 \%$ commission charged by the company was too high. However, there is little other evidence of protest in the country, and working tables held by the Peruvian Congress about its legal project struggled to identify official representatives of the taxi sector to participate (Valga Gutierrez, 2020, p. 38). Meanwhile, ride-hailing has been widely embraced in Peru by both drivers and passengers (Valga Gutierrez, 2020, p. 35).

The public sector faced different pressures around taxi regulation in these two countries. Chile faced an end run situation, in which innovators raised the same underlying policy concerns as incumbents, but were working outside of regulatory frameworks. Chile's new law takes a neutral position on taxi market conditions that balances benefits and risks for all actors within this space.

Peru, on the other hand, is in some ways facing a solution situation, since the introduction of ride hailing offered a means to address the long-time problem of informality in the sector. This aligns with von Vacano's (2017) argument that the introduction of ride-hailing systems into countries with highly informal taxi services can create improvements by formalising employment and service offerings ( $p$. 100). If we apply the logic of Biber et al.s framework (2017), new regulation would not be strictly necessary in Peru's case, since the introduction of ride-hailing offers benefits, and those benefits may outweigh the costs. Peru's legal project was introduced to enhance ride-hailing by ensuring protection of consumer rights in this new space: "The majority of the congressional leaders in the debate agreed and had the same reading of the problem: offer security given high rates of citizen violence and defend the rights of consumers" (Valga Gutierrez, 2020, p. 39). But despite being a pro-market regulation, this legal project failed to pass into law. Why is this?

Chile and Peru's legal projects reveal a significant difference in business strategy between Uber and its main competitor, Cabify (personal correspondence, April 10, 2019). Cabify sets up offices and constitutes itself legally in countries where it operates, whereas Uber inserts its application into local markets from afar. While both are multinationals, this sets up a contest between a localised operation and a 
global operation. The introduction of legislation that localises operations provides a competitive advantage to Cabify, which is already positioned within Peru and Chile to operate under these conditions.

Chile's new law gives Cabify a competitive advantage against Uber, but not against incumbent taxi companies. Chilean incumbents gain by already having the means to adhere to insurance, safety, training and signage regulations. And the law can be justified on consumer rights and customer safety grounds. This dynamic allowed Chilean regulators to sustain an impartial regulatory approach.

In Peru, on the other hand, when the legal project was sent from Congress to the executive it was rejected by President Vizcarra (Vizcarra \& Villanueva, 2018). According to a local source, Uber leveraged its membership in ComexPeru to pressure Vizcarra to reject the law (personal correspondence, April 10, 2019). Comex represents foreign business interests in Peru and has considerable power given the openness of Peru's economy. It launched a media campaign on Uber's behalf which argued that "the collaborative economy introduces healthy competition" in ways that "help to resolve Peruvian challenges such as inequality, self-sufficiency and informality" (Gestión, 2019a) and chastised regulators for exhibiting "technophobia" and "wanting to corset new relations created by the digital economy into traditional models" (Castro, 2019). Meanwhile, Uber introduced new safety features to better serve their clients, a move which the press characterised as "getting ahead of Congress" (Gestión, 2019b). These interventions bore fruit because Comex has "weight in the Ministry of Finance and that, at the end of the day, this is the entity which most influences approval of legislative initiatives within the Executive" (Valga Gutierrez, 2000, p. 40).

These two cases suggest that the Chilean government has more regulatory autonomy than the Peruvian one when it comes to addressing the platform economy, particularly vis-à-vis transnational companies. However, Chile continued to endorse the pro-free market regulatory approach that is typical of that country. In comparison, the inability to pass even a consumer protection law in Peru demonstrates the very narrow space to manoeuvre for platform policymakers in that country. And yet, within the context of a pro-market regulatory state, the fact that the Peruvian congress contemplated a policy that might favour companies that at least establish some operations in the country suggests that there is a desire to intervene in the economy in proactive ways. Overall, this analysis raises questions about the type of capacity and negotiating tactics required to advance more developmentalist policies in the platform economy, particularly in the face of powerful multinational actors. 


\section{Lodging: leveraging societal resources for socially conscious forms of production}

Where at first the disruptions caused by platformisation in the lodging sector appear to be easily resolved by striking a new balance between stakeholders, on closer examination this case demonstrates how platformisation challenges the definition of resources and how they might be mobilised for development.

In all four countries, early regulatory efforts by municipalities and federal actors in the digital lodging sector raised concerns in the traditional hotel sector. For example, in Mexico City a 3\% tax on AirBnB bookings (CDMX, 2017) was challenged by the Mexican Association of Hotels and Motels which pointed out that traditional hotels pay $16 \%$ value added tax plus $35 \%$ income tax (Martínez, 2017). And, in Colombia, the Ministry of Commerce, Industry and Tourism's policy only required hosts to register their operations with the state (Vida, 2017) while the traditional hotel sector was required to register operations with tourism, migration and tax authorities and meet significant minimum requirements for health and safety (Corrales, 2018). The Colombian Association for Hotels and Tourism (Cotelco) noted a $1.8 \%$ drop in hotel occupation and a $2.8 \%$ drop in hotel employment from 2016-2018 even as tourist numbers rose by 17\% (Corrales, 2018, p. 14) prompting them to suggest that the Colombian policy promoted unfair competition ( $\mathrm{Ci}$ fuentes, 2020).

Representatives of the hotel sector have made various efforts to defend their established position by expressing instrumental power in policy spaces. For example, in Mexico, the current Tourism Secretary, Miguel Torruco Marqués came to the role after serving simultaneously as the President of the Mexican Association of Hotels and Motels for the Federal District (2012-2017) and the Secretary of Tourism for the Federal District. As of 2019, he was carrying out an audit of digital lodging in Mexico, and working with the Ministry of Finance and Public Credit to regulate digital lodging platforms (Herrera, 2019), however to date no policy proposals have emerged.

In Peru, the former Minister of Tourism, Rogers Valencia Espinoza, came to his position after serving as President of the Regional Council for Tourism of Cusco, and as a member of the Peruvian Association for Hotels, Restaurants and Associated Entities (AHORA). In 2018, he proposed a Ministerial Resolution to the Peruvian Congress (Congreso de la República de Perú, 2018a) that would have made it illegal to operate short term rental operations unless all formal hotels were already full (Guerrero, 2018). ComexPerú (discussed earlier) which also represents AirBnB, is- 
sued statements in opposition to the new regulation (Riofrío, 2018) and legal experts pointed out that the proposed reform impinged on several other legal rights (Guerrero, 2018). Valencia Espinoza was shuffled into a lesser role as Minister of Foreign Trade and Tourism in April 2018 and the proposed regulatory reform was shelved.

In these examples, lodging innovations have been treated like an end run, and proposed policy solutions have gravitated towards levelling the playing field for lodging providers. But in fact, the policy dilemma is considerably more complex in this case. Digital lodging has become a mechanism that drives the transformation of housing stock into an investment asset since platform innovations allow property owners to earn more from short term rentals than from long-term renters. This has led to the emergence of both professional AirBnB property managers and investors, and AirBnB investment schemes. For example, in Chile, a 2019 background document produced by a Member of Congress notes that " $40 \%$ of advertisements belong to hosts who have multiple advertisements which, since it is unlikely that they live in all of their properties, correspond to commercial operators of informal accommodations" (Winter Etcheberry, 2019). In Colombia developers such as Korn Architects have begun to build AirBnB apartment towers as an investment opportunity (Portafolio, 2018).

These types of schemes, if they prove successful, could offer opportunities for small scale investment that facilitate upward mobility, but only if lodging operations do not become concentrated in a few hands. To complicate matters, there are no restrictions on foreign property ownership in any of the four countries under consideration, which opens the housing stock to the possibility of foreign capitalisation. Allowing housing to become an investment asset has created well-documented problems with housing affordability and availability in cities around the world (Kusisto \& Grant, 2019) which is not in the best interests of social equity. This means that the regulatory dilemma in the lodging sector is not just about levelling the playing field between hoteliers and homeowners. It is more broadly about protecting housing as a matter of equity and quality of life, and also regulating real estate to protect against housing bubbles or collapses. What at first appeared to be an end run in the eyes of hotel associations and some policymakers has revealed itself to be a policy gap, since digital lodging has created entirely new concerns.

Some legal projects are beginning to emerge to address these policy gaps. In October 2019 the Chilean Chamber of Deputies saw a motion to modify Law 20.423 Institutional System for the Development of Tourism (Winter Etcheberry, 2019). It 
aimed to "regulate temporary accommodations to ensure the interests of the users and the communities that experience their effects" (p. 2). It proposed limiting short-term rentals to 90 days per unit per year as a means to control the incentive mechanisms driving investment in housing stock. It also proposed new municipal fines, as well as changes to the regulation of condominiums that would limit individuals to a single vote, regardless of the number of units they own. ${ }^{4}$ This proposal might be considered developmental in that it seeks to protect the economic potential of micro-lodging for small-scale operators, while also limiting concentration of power in the hands of housing investors. It is also interesting to note that the motion presenting the legal project explicitly cites corporate actors' unwillingness to share data about their operations with the state, and the difficulties that this creates for crafting regulation (ibid., p. 3).

The Chilean example can be contrasted with a recent municipal legal project put forward in July, 2020 that proposes a ban on the short term rental of condominium units in Mexico City. The document argues that "For no motive can they be used for temporary accommodation such as what is offered by platforms like AirBnB and other similar modalities which are in contravention of condominium, business, sanitation, civil protection, fiscal and other norms" (Ortega \& Navarrete, 2020). Here rather than exploring socially relevant applications of the platform economic form, the policy seeks to engineer a separation between social and productive spaces.

Because the platform lodging sector presents policy gaps that demand novel regulatory approaches, there may be greater possibility for policy innovations that include more developmental orientations. However the brief exploration presented here suggests the complexity of this proposition. A developmentally minded policymaker could perhaps create opportunities to leverage housing stock for investment, economic growth, economic diversification, and microenterprise if this is in the interest of the community; but such a policy would also need to resist pressures from international investors and tourism operators, as well as real estate companies and property holding elites. This raises questions about how platform developmentalism could or should leverage community resources, and how best it can incentivise socially beneficial forms of capitalisation.

4. This project was remitted to committee, and as of September 2020, it had not yet returned to Congress for discussion. 


\section{Fintech: crafting state-market collaborations that advance developmental objectives}

Fintech demonstrates the challenges and potential of state-market collaborations to advance developmental objectives. It describes the use of digital technologies to create innovations in financial business models (Anagnostopoulos, 2018). These include crowd-based means to access capital, online or mobile banking applications, and new ways of processing transactions in the marketplace. Fintech is often itself platformised, as in the case of crowd-based financial services, and it also drives the larger platform ecosystem by enabling digital transactions.

Mexico's new Fintech Law, which came into force in March 2018 (Cámara de Diputados de México, 2018), is the most advanced of the four countries under consideration (Aleman, 2020). Mexico designed a totally new legal framework in which "fintech activities are regulated similarly to other financial services, such as banking and securities services" (Bolaños \& Botello, 2019, p. 25). The new law creates standards for the operation of crowdfunding, lending and equity schemes, and the operation of virtual wallets. It also establishes a regulatory framework for developing new fintech products or services under the supervision of the banking authority. These sandboxes are meant to offer a way for regulators and innovators to learn and grow together. Finally, the law also allows banks to invest in or acquire fintech companies, or companies that develop fintech innovations.

Mexico's law offers a response to issues that have been the subject of intense debate within the fintech sector in the countries under study. When fintech innovations such as crowdfunding first arose in the region they created an end run situation. Fintech innovators claimed that existing regulations did not apply to them, however, regulators often claimed that they did. In Chile, for example, crowdfunding initiatives exist without the benefit of crowdfunding regulation, however "Chilean law forbids raising funds from the public (except for banks) and crowdfunding has been seen as breaching such a restriction" (Peralta \& Noriega, 2019, p. 6). ${ }^{5}$ This situation leaves both innovators and regulators in a difficult position.

In these countries, existing regulatory frameworks, as well as the banking sector they refer to, were developed to support big capital and big investments. In contrast, fintech innovations have been oriented towards servicing small scale banking and micro transactions. Given that financial inclusion has been historically low in these countries, this casts fintech in a favourable light. However regulators have

5. Chile is otherwise considered to be the least advanced in terms of fintech regulation in Latin America (Quirós, 2019). 
been cautious about the potential risks of digital banking innovations. For example, in the debates that arose around Mexico's fintech law, the Mexican National Commission for Protection and Defence of Users of Financial Services (CONDUSEF) argued that informal banking mechanisms contradicted the goals of financial inclusion by putting citizens at risk (Foro Jurídico, 2017). To complicate matters, it is difficult for authorities to keep up with the innovations produced by the fintech sector, and in particular, to distinguish serious innovators from those looking to exploit regulatory loopholes for personal gain.

Some regulators have managed these contradictions by asserting authority over crowd-based initiatives and creating regulatory sandboxes that allow corporate actors to experiment with financial innovations under the supervision of the regulator. Sandbox frameworks are often paired with regulations that allow banks to invest in or purchase fintech companies, thus providing a means to fund fintech innovations. For example, in 2018 the Colombian Supervisor of Finance issued Decree 1357 which regulated debt and equity crowdfunding, it created a fintech sandbox, and it issued Decree 2443 which authorised credit institutions, financial services entities and capitalisation companies to invest in fintech companies that develop technologies directly related to the corporate activities of the investor.

But this move provoked pushback from Colombian fintech start-ups. The new regulatory arrangement effectively formalises fintech, and ties access to investment financing to the needs of existing financial institutions. A representative of industry association Colombia Fintech complained about the new scenario saying that "The Supervisor doesn't want to put itself in problems with the banks, so it is taking a lukewarm position, but fintech companies do need a regulatory framework, because each time they try to do something, the Bank of the Republic, the Ministry of Finance, or the very same Supervisor of Finance, tells them that they can't do it because it is too risky" (quoted in García, 2018). This can be read as a call for greater transparency in the operations of the Supervisor of Finance which is perceived to be in the pocket of Colombia's traditional banking sector. If this is true, then it suggests that incumbent banking players may be influencing policy in ways that undermine competition.

Peru has taken a different approach. There are currently no restrictions on investment by Peruvian financial entities in fintech companies, and there is no regulatory sandbox. Instead, fintech innovation has been left to the private sector. ${ }^{6}$ At the 
end of 2018, the Peruvian fintech company Culqi, which created payment gateway services for authorising credit cards at point of sale, was purchased by Banco de Crédito del Perú. This transaction was considered a success because it generated new business for a large Peruvian company, while at the same time facilitating access to international credit card transactions at competitive rates (Alcázar \& Sánchez, 2019). This could be considered a developmental outcome since it drives economic growth while also reducing costs for small businesses and consumers.

But if platform developmentalism takes seriously the need to put data and information systems at the centre of national development planning, Peru's fintech deal needs careful analysis, because credit card companies are key sources of data for global consumer data brokerages (Christl, 2017). Indeed, a study of fintech sandboxes in 28 countries by the Consultative Group to Assist the Poor (CGAP) and the World Bank found that sandbox projects overwhelmingly focus on payments services and market infrastructure, and that "most sandbox-tested innovations do not target excluded and underserved customers at the base of the pyramid" (Jenik et al., 2019, n.p.). ${ }^{7}$ The report concludes by recommending that regulators create financial inclusion themed regulatory sandboxes so that state and private actors can co-design policies and technologies that together address barriers to financial inclusion. Given the growing value of data, regulators could also use sandboxes to experiment with novel forms of data intermediation such as data trusts in order to ensure responsible capitalisation of this resource within the national economy. Two observations arise out of this analysis, which are the significance of novel models of state-business collaboration to platform developmentalism, and also the need to consider the relationship between data and money in creating policy for national economic and social well being.

\section{Conclusions}

The idea of platform developmentalism challenges us to shift the notion of a platform society (van Dijck et al., 2018) from an ontological to a normative position, and to address platform business models as strategic choices rather than social outcomes. It means asking, given the technologies at our disposal, what kind of society do we want? How can these technologies best be applied to mobilise society's resources to achieve those outcomes?

September 28, 2018. http://www.leyes.congreso.gob.pe/Documentos/2016_2021/Proyectos_de_Ley_y_de_Resoluciones_Legislativas/PL0340320180918.pdf

7. https://www.cgap.org/blog/do-regulatory-sandboxes-impact-financial-inclusion-look-data 
This means moving away from self-regulation by business interests, as well as the elision of societal governance with platform governance. Rather than looking at data and information systems as a way to connect local markets with global capitalist circuits, platform developmentalism argues that governments should steward their data and information resources as potential sources of economic growth and social wellbeing. Achieving this goal implies taking up new approaches to policy-making. It would require shifting away from small state regulatory approaches and towards more interventionist forms of state management.

In the four countries considered here, Chile, Colombia, Mexico and Peru, this would mean taking on powerful actors who have a vested interest in protecting limited state intervention in economic affairs. The challenges of overcoming historically embedded hegemonic coalitions and fundamentally shifting a nation's approach to regulating capitalism are too complex to address here. What can be said is that the role of the 'digital developmental state', as Heeks (2018, p. 12) calls it, is a pressing research agenda. This paper offers guidance for researching "the processes and structures - particularly the politics and political economy - of digital economy policy-making and implementation in developing countries" (ibid., p. 11). In doing so, it moves the developmental research agenda away from treating platforms like a technological intervention (Koskinen et al., 2019) and rather places our focus on the context in which platformisation creates effects.

With this in mind, if we are to find new regulatory pathways for the platform economy, I agree with van Dijck et al.s (2018) call to analyse "how societal values form the heart of debates over private gain versus public interest" in platform business models (p. 140). They go on to say that "Articulating which values are contested by whom in which context may help reshape the current platform ecosystem in ways that make it more responsive to public concerns" (ibid.). However, while this is a great agenda for research, I am unsure why citizens would put their trust in the rather vague and faceless, and for Latin American countries, often foreign, platform ecosystems. In that regard, if people are to understand platformisation and put pressure on governments to properly regulate this business model, community engaged research is required on personal data literacy (D'Ignazio, 2017), especially where it serves to articulate local social values around data and information systems (Reilly, 2020).

These can in turn serve as alternative frameworks for locally relevant policy research. In particular, platformisation involves a reorganisation of the boundary between social space and productive space, as when our cars or homes, indeed our personal identity, become the subjects of new forms of commodification. This has 
important implications for developmentalism, which by definition must seek a balance between economic growth and social equity. Where does the community draw the line when it comes to leveraging its resources for productivity? Here research is needed into the implications of governance frameworks that put people at the centre of regimes of production based on personal data and information systems (Lehtiniemi \& Haapoja, 2020).

Meanwhile, since the platform ecosystem is dominated by global corporations, research is urgently required about how small states can best negotiate with transnational platform actors to extract benefits for their nation. Egan (2010) points out that the balance of power between states and multinationals operates differently in resource extraction versus manufacturing. The same will be true of platformisation, because data resources are valued, cultivated and traded differently. When should states open their borders to platform multinationals, and how can they best position themselves for that negotiation to extract maximum developmental benefits?

Finally, as platformisation involves rapid technological innovation, it is often argued that governments should leave the heavy lifting to the private sector. But the experience of fintech shows us that this need not be the case. Platform developmentalism requires innovative models of corporate-government innovation that can mobilise investment in ways that advance community agendas. Some readers may wonder if platform developmentalism means putting more data in the hands of state officials, but I do not think this need necessarily be the case. Rather, drawing on Jenik et al. (2019), research into sandbox models could explore regulatory avenues that allow private actors to work with personal data through fiduciary arrangements in ways that reinvest in community wellbeing. This would represent a true recognition of the close relationship between data and economic value in the platform economy.

To conclude, the technocentric assumption that platform innovation will somehow lead directly to development is a shallow proposition that ignores the political economy of the digital economy. Where platformisation can offer pathways beyond structural barriers, it could offer fundamental opportunities to advance development goals. These opportunities will differ from one sector to another, and will take shape differently depending on existing hegemonic coalitions. Comparative analysis of policy struggles and their outcomes can offer a powerful means to better understand how platformisation is reshaping development processes, while also offering insights into the types of policies required to put platformisation to work for the betterment of communities. 


\section{ACKNOWLEDGEMENTS}

This paper was written with the support of the Social Sciences and Humanities Research Council (SSHRC) of Canada. Thank you to Luis Lozano-Paredes for his assistance with field research.

\section{References}

Alcázar, R., \& Sánchez, M. (2019). Peru. In Lloreda Camacho \& Co (Ed.), LATAM Fintech Regulation (2nd ed., pp. 34-41). Lloreda Camacho \& Co. https://loredacamacho.com/wp-content/uploads/201 9/12/LATAMFINTECHREGULATION-NE-EN-111219.pdf

Aleman, X. (2020). Fintech regulations in Latin America could fuel growth or freeze out startups. In TechCrunch. https://techcrunch.com/2020/05/27/fintech-regulations-in-latin-america-could-fuel-gro wth-or-freeze-out-startups/

Amsden, A. H. (1989). Asia's Next Giant: South Korea and Late Industrialization. Oxford University Press. https://doi.org/10.1093/0195076036.001.0001

Anagnostopoulos, I. (2018). Fintech and regtech: Impact on regulators and banks. Journal of Economics and Business, 100, 7-25. https://doi.org/10.1016/j.jeconbus.2018.07.003

Andrea, M. (2020). Book Review: The Platform Society: Public Values in a Connective World. International Journal of Communication, 14, 781-783. https://ijoc.org/index.php/ijoc/article/view/142 71

Artopoulos, A., Cancela, V., Huarte, J., \& Rivoir, A. (2019). El último kilómetro del e-commerce. Segunda brecha (digital) del desarrollo informacional. In A. L. Rivoir \& M. J. Morales (Eds.), Tecnologías Digitales: Miradas Críticas de la Apropiación en América Latina (pp. 259-282). CLACSO.

Bagchi, A. (2000). The past and the future of the developmental state. Journal of World-Systems Research, 2, 398-442. https://doi.org/10.5195/jwsr.2000.216

Barros, C. (2018). Tecnologías disruptivas: Regulación de plataformas digitales. La Comisión Nacional de Productividad. http://www.comisiondeproductividad.cl/2018/04/tecnologias-disruptivas-regulaci on-de-plataformas-digitales/

Biber, E., Light, S. E., Ruhl, J. B., \& Salzman, J. (2017). Regulating business innovation as policy disruption: From the Model T to Airbnb. Vanderbilt Law Review, 70(5), 1561-1625. https://cdn.vande rbilt.edu/vu-wp0/wp-content/uploads/sites/278/2017/10/06190338/Regulating-Business-Innovatio n-as-Policy-Disruption.pdf

Bizberg, I., \& Théret, B. (2012). La diversidad de los capitalismos latinoamericanos: Los casos de Argentina, Brasil y México. Noticias de la Regulación, 61, 1-22.

Bolaños, I., \& Botello, M. (2019). Mexico. In Lloreda Camacho \& Co (Ed.), LATAM Fintech Regulation (2nd ed., pp. 25-33). Lloreda Camacho \& Co. https://loredacamacho.com/wp-content/uploads/201 9/12/LATAMFINTECHREGULATION-NE-EN-111219.pdf 
Boschi, R. R. (2011). Variedades de Capitalismo, Política e Desenvolvimento na América Latina. Editora UFMG.

Bresser-Pereira, L., \& Theuer, D. (2012, May 25). Latin America: After the neoliberal years, is the developmental state back in? Latin American Studies Association Annual Congress (LASA-2012), San Francisco. http://www.bresserpereira.org.br/papers/2012/373-Developmental-State-Back-in-Latin-A merica-Theuer.pdf

Bril-Mascarenhas, T., \& Madariaga, A. (2017). Business power and the minimal state: The defeat of industrial policy in Chile. Journal of Development Studies, 55(6), 1047-1066. https://doi.org/10.1080/ 00220388.2017.1417587

Regula a las aplicaciones de transporte remunerado de pasajeros y los servicios que a través de ellas se presten, (2018). https://www.camara.cl/pley/pley_detalle.aspx?prmID=12456\&prmBOLETI $\mathrm{N}=11934-15=$

Ley para regular las instituciones de tecnología financiera, Pub. L. No. DOF 09-03-2018 (2018). http s://static1.squarespace.com/static/58d2d686ff7c50366a50805d/t/5ac450630e2e72d53c20f091/15 22815078233/LRITF_090318.pdf

Castillo, M., Rovira, S., Peres, W., Porcile, G., Rodríguez, A., Brossard, F., Rodrigues, M., Patiño, A., \& Valderrama, P. (2016). Science, technology and innovation in the digital economy: The state of the art in Latin America and the Caribbean. Conference on Science, Innovation and Information and Communications Technologies of ECLAC, San Jose. https://repositorio.cepal.org/bitstream/handle/1 1362/40840/S1600832_en.pdf?sequence=1 \&isAllowed=y

C.D.M.X. (2017, May 11). Regula Gobierno de la Ciudad de México operación de AirBnB. Finanzas CDMX. http://www.finanzas.cdmx.gob.mx/comunicacion/nota/regula-gobierno-de-la-ciudad-de-me xico-operacion-de-airbnb

Christl, W. (2017). Corporate Surveillance in Everyday Life [Report]. Cracked Labs. https://crackedlab s.org/en/corporate-surveillance

Cifuentes, L. F. (2020). Cotelco destaca acuerdo entre el Gobierno y la Plataforma Airbnb. In RCN Radio. https://www.rcnradio.com/colombia/cotelco-destaca-acuerdo-entre-el-gobieno-y-la-platafor ma-airbnb

Cimoli, M., \& Rovira, S. (2008). Elites and Structural Inertia in Latin America: An Introductory Note on the Political Economy of Development. Journal of Economic Issues, 42(2), 327-347. https://doi.or $\mathrm{g} / 10.1080 / 00213624.2008 .11507142$

Cohen, R. (1987). To become cabdriver in Lima, Peru, start car, start cruising. The Wall Street Journal.

Congreso Perú. (2016). Proyecto de ley que crea y regula el servicio privado de transporte a través de plataformas tecnológicas. http://www.leyes.congreso.gob.pe/Documentos/2016_2021/Proyectos_d e_Ley_y_de_Resoluciones_Legislativas/PL0150520170608.pdf

Disponen la prepublicación del proyecto de Reglamento de Establecimientos de Hospedaje en el Portal Institucional del Ministerio. Resolution 170-2018-MINCETUR, (2018). https://hiperderecho.or g/wp-content/uploads/2018/06/proyecto_reglamento_hospedajes_mincetur-2.pdf

Corrales, M. (2018). ¿Hay cama para tanta gente? Un Análisis sobre la regulación de AirBnB en Colombia[Undergraduate Thesis, Facultad de Ciencias Jurídicas]. http://hdl.handle.net/10554/36479

Crabtree, J., \& Durand, F. (2017). Peru: Elite Power and Political Capture. Zed Books. 
Diaz, R. (2019, April 5). ¿Final conflicto entre taxistas y ubers? Esto busca la ley de aplicaciones de transporte que pasó al Senado. El Definido. https://eldefinido.cl/actualidad/pais/10986/Fin-al-confli cto-entre-taxistas-y-ubers-Esto-busca-la-ley-de-aplicaciones-de-transporte-que-paso-al-Senado/

D'Ignazio, C. (2017). Creative data literacy: Bridging the gap between the data-haves and data-have nots. Information Design Journal, 23, 6-18. https://doi.org/10.1075/idj.23.1.03dig

Egan, P. (2010). Hard bargains: The impact of multinational corporations on economic reform in Latin America. Latin American Politics and Society, 52(1), 1-32. https://doi.org/10.1111/j.1548-245 6.2010.00072.x

El Comercio. (2016, September 3). Taxistas realizaron caravana de protesta contra Uber. El Comercio. https://elcomercio.pe/lima/taxistas-realizaron-caravana-protesta-uber-fotos-254353-noticia/

Evans, P. (1995). Embedded Autonomy: States and Industrial Transformation. Princeton University Press.

Ezeomah, B., \& Duncombe, R. (2019). The Role of Digital Platforms in Disrupting Agricultural Value Chains in Developing Countries. In P. Nielsen \& H. C. Kimaro (Eds.), Information and Communication Technologies for Development. Strengthening Southern-Driven Cooperation as a Catalyst for ICT4D (Vol. 551, pp. 231-247). Springer International Publishing. https://doi.org/10.1007/978-3-030-1840 $0-119$

Fairfield, T. (2015). Structural power in comparative political economy: Perspectives from policy formulation in Latin America. Business and Politics, 17(3), 411-441. https://doi.org/10.1515/bap-20 14-0047

Foro Jurídico. (2017, September 29). Ley Fintech: Acelerando la inclusión financiera. Foro Jurídico. htt ps://forojuridico.mx/ley-fintech-acelerando-la-inclusion-financiera/

Franz, T. (2018). Power balances, transnational elites, and local economic governance: The political economy of development in Medellín. Local Economy: The Journal of the Local Economy Policy Unit, 33(1), 85-109. https://doi.org/10.1177/0269094218755560

Gaitán, F., \& Boschi, R. (2015). State-business-labour relations and patterns of development in Latin America. In M. Ebenau, I. Bruff, \& C. May (Eds.), New Directions in Comparative Capitalisms Research (pp. 172-188). Palgrave Macmillan. https://doi.org/10.1057/9781137444615_11

Galo, I. (2016). Economía Colaborativa En América Latina [Report]. Interamerican Development Bank. https://publications.iadb.org/es/economia-colaborativa-en-america-latina

García, C. (2018, September 10). Fuerte polémica por regulación para firmas de tecnología financiera. El Tiempo. https://www.eltiempo.com/economia/sector-financiero/cual-es-la-regulacionfintech-en-colombia-266774

Gestión. (2019a). Comex: Economía digital puede ayudar a resolver retos como la desigualdad en Perú. In Gestión. https://gestion.pe/economia/comex-economia-digital-ayudar-resolver-retos-desigu aldad-peru-274430-noticia/

Gestión. (2019b, September). Uber se adelanta al Congreso e implementa botón de pánico. Gestión. Gestión. https://gestion.pe/economia/empresas/uber-adelanta-congreso-e-implementa-boton-panic o-243587-noticia/

Gillespie, T. (2010). The politics of 'platforms'. 12(3), 347-364. https://doi.org/10.1177/14614448093 42738 
Graham, M., Hjorth, I., \& Lehdonvirta, V. (2017). Digital labour and development: Impacts of global digital labour platforms and the gig economy on worker livelihoods. Transfer: European Review of Labour and Research, 23(2), 125-162. https://doi.org/10.1177/1024258916687250

Guerrero, C. (2018, June). Mincetur busca prohibir que peruanos alquilen sus viviendas a través de Airbnb [Blog post]. Hiperderecho. https://hiperderecho.org/2018/06/mincetur-busca-prohibir-que-pe ruanos-alquilen-sus-viviendas-a-traves-de-airbnb/

Gurumurthy, A. (2018). Polities for the platform economy: Current trends and future directions [Report]. IT for Change. https://itforchange.net/platformpolitics/wp-content/uploads/2018/09/Mid_Project_R eflections_2018.pdf

Gurumurthy, A., Bharthur, D., Chami, N., \& Narayan, V. (2020). Unskewing the Data Value Chain: A Policy Research Project for Equitable Platform Economies [Background Paper]. IT for Change. https://it forchange.net/unskewing-data-value-chain-a-policy-research-project-for-equitable-platform-econo mies

Guzmán, J. A. (2016). El capitalismo jerárquico de Chile difícilmente puede ser defendido por los partidarios del libre mercado. Centro de Investigación Periodística. https://ciperchile.cl/2016/05/04/e l-capitalismo-jerarquico-de-chile-dificilmente-puede-ser-defendido-por-los-partidarios-del-libre-m ercado/

Haggard, S. (2018). Developmental States. Cambridge University Press. https://doi.org/10.1017/9781 108552738

Hagiu, A., \& Wright, J. (2011). Multi-sided platforms (Working Paper No. 12-024). Harvard Business School. https://hbswk.hbs.edu/item/6681.html

Heeks, R. (2018). Digital economies and development: A research agenda. (Development Implications of Digital Economies) [Briefing]. Centre for Development Informatics, Global Development Institute, University of Manchester. https://diodeweb.files.wordpress.com/2018/10/digital-economy-and-deve lopment-research-agenda.pdf

Hernández López, M. (2017). Variedades de capitalismo, implicaciones para el desarrollo de América Latina. Economía Teoría y Práctica. Nueva Época, 46, 195-226. https://doi.org/10.24275/ety puam/ne/462017/hernandezlopez

Herrera, M. (2019). Sectur y la SHCP buscan generar marcos regulatorios para plataformas de hospedaje. In Inmobiliare. https://inmobiliare.com/sectur-y-la-shcp-buscan-generar-marcos-regulat orios-para-plataformas-de-hospedaje/

Hira, A., \& Reilly, K. (2017). The emergence of the sharing economy: Implications for development. Journal of Developing Societies, 33(2), 175-190. https://doi.org/10.1177/0169796X17710071

Jara Román, S. (2019, September 2). El secreto informe tributario de los super ricos que el SII hizo desaparecer. El Desconcierto. https://www.eldesconcierto.cl/2019/09/02/el-secreto-informe-tributari o-de-los-super-ricos-que-el-sii-hizo-desaparecer/

Jayasuriya, K. (2001). Globalization and the changing architecture of the state: The politics of the regulatory state and the politics of negative co-ordination. Journal of European Public Policy, 8(1), 101-123. https://doi.org/10.1080/1350176001001859

Johnson, C. (1982). MITI and the Japanese Miracle. Stanford University Press.

Katz, R. (2015). El ecosistema y la economía digital en América Latina. Fundación Telefónica; Editorial Ariel. https://repositorio.cepal.org/bitstream/handle/11362/38916/1/ecosistema_digital_AL.pdf 
Kenney, M., \& Zysman, J. (2016). The rise of the platform economy. Issues in Science and Technology, XXXII(3). http://issues.org/32-3/the-rise-of-the-platform-economy/.

Koskinen, K., Bonina, C., \& Eaton, B. (2018). Digital platforms in the Global South: Foundations and research agenda (Paper No. 08; Development Implications of Digital Economies). Centre for Development Informatics, Global Development Institute, University of Manchester. https://diodewe b.files.wordpress.com/2018/10/digital-platforms-diode-paper.pdf

Kusisto, L., \& Grant, P. (2019, April 2). Affordable housing crisis spreads throughout world; Shortages persist despite millions of dollars invested and hundreds of thousands of units built. The Wall Street Journal.

Lehtiniemi, T., \& Haapoja, J. (2020). Data agency at stake: MyData activism and alternative frames of equal participation. New Media \& Society, 22(1), 87-104. https://doi.org/10.1177/146144481986 1955

Levi-Faur, D. (2005). The global diffusion of regulatory capitalism. Annals of the American Academy of Political and Social Science, 598(1), 12-32. https://doi.org/10.1177/0002716204272371

López García, A. (2017, January 23). Oligarchic politics in Latin America. VoxUkraine. https://voxukrai ne.org/en/oligarchic-politics-en/.

López-Obrador, A. (2018). Primer discurso como Presidente [Speech]. https://www.youtube.com/watc $h ? v=e K I Z L D H 3 t \_U$.

Martínez, E. (2017, July 20). Hoteleros quieren regulación federal para Airbnb y HomeAway. El Financiero. https://www.elfinanciero.com.mx/empresas/hoteleros-quieren-regulacion-federal-para-a irbnb-y-homeaway.html

O.E.C.D. (2016). Start-up Latin America 2016: Building an Innovative Future. Assessment and recommendations(Development Centre Studies). OECD Publishing. https://www.oecd.org/dev/americ as/Startups2016-Assessment-and-Recommendations.pdf

Ondetti, G. (2017). El poder de las preferencias. Las élites económicas y tributación baja en México. Revista Mexicana de Ciencias Políticas y Sociales, 62(231), 47-76. https://doi.org/10.1016/S0185-191 8(17)30038-7

Ortega, E., \& Navarrete, F. (2020, July 20). Diputada de Morena propone ley que prohíbe rentar condominios en Airbnb en la CDMX. El Financiero. https://www.elfinanciero.com.mx/empresas/diput ada-de-morena-propone-ley-que-prohibe-rentar-condominios-en-airbnb-en-la-cdmx

Osborne, D., \& Gaebler, T. (1992). Reinventing Government: How the Entrepreneurial Spirit is Transforming the Public Sector. Addison-Wesley.

Parthasarathy, B., \& Matilal, O. (2019). The platform economy and digital work: A developmental state perspective(Paper No. 9; Development Implications of Digital Economies). Centre for Development Informatics, Global Development Institute, University of Manchester. https://diodeweb.files.wordpre ss.com/2019/04/developmental-state-diode-paper-final.pdf

Pashley, A., \& Hidalgo López, C. (2014, July 16). Por qué los taxistas de Lima ven con recelo la nueva normativa que rige la apariencia de los taxis. Global Voices. https://es.globalvoices.org/2014/ 07/16/por-que-los-taxistas-de-lima-ven-con-recelo-la-nueva-normativa-que-rige-la-estetica-de-lo s-taxis/

Peralta, D., \& Noriega, F. (2019). Colombia. In Lloreda Camacho \& Co (Ed.), LATAM Fintech Regulation (2nd ed., pp. 11-17). Lloreda Camacho \& Co. https://loredacamacho.com/wp-content/uploads/201 


\section{9/12/LATAMFINTECHREGULATION-NE-EN-111219.pdf}

Pérez Caldentey, E. (2008). The concept and evolution of the developmental state. International Journal of Political Economy, 37(3), 27-53. https://doi.org/10.2753/IJP0891-1916370302

Portafolio. (2018). Nuevo edificio en Bogotá se arrendará bajo la modalidad de Airbnb. In Portafolio. https://www.portafolio.co/negocios/airbnb-tendra-un-nuevo-edificio-en-bogota-y-busca-inversionis tas-522593

Quirós, F. (2019, March 29). Afirman que, en materia de regulación Fintech, Chile es el país que menos avanzó en la región. Cointelegraph. https://es.cointelegraph.com/news/in-terms-of-fintech-re gulation-chile-is-the-least-advanced-country-in-the-region-acoording-to-fintechile

Reilly, K. (2017, June 9). Logistics brokerage, development and the urban economy. Presented at Hacia Ciudades Colaborativas: Desarrollo Urbano Integral Y Economía Colaborativa, Buenos Aires, Argentina [Talk]. CIPPEC XII Foro Lideres de Ciudades. https://www.youtube.com/watch?v=U68garla2NE

Reilly, K. (2020). The challenge of decolonizing big data through Citizen Data Audits [1/3] [Blog post]. In BigDataSur. https://data-activism.net/2020/04/bigdatasur-the-challenge-of-decolonizing-b ig-data-through-citizen-data-audits-1-3/

RioFrío, M. (2018, June). ¿En qué consiste la norma que traba el despegue de Airbnb? El Comercio. ht tps://elcomercio.pe/economia/negocios/consiste-norma-traba-desplieuge-airbnb-noticia-529144-n oticia/

Rodriguez, K., \& Alimonti, V. (2020). A look-back and ahead on data protection in Latin America and Spain. [Blog post]. Electronic Frontier Foundation Deeplinks. https://www.eff.org/deeplinks/2020/09/l ook-back-and-ahead-data-protection-latin-america-and-spain

Routley, L. (2012). Developmental states: A review of the literature (Working Paper No. 03). School of Environment and Development, University of Manchester. https://doi.org/10.2139/ssrn.2141837

Sandbrook, R., Edelman, M., Heller, P., \& Teichman, J. (2007). Social Democracy in the Global Periphery: Origins, Challenges, Prospects. https://doi.org/10.1017/СB09780511491139

Saucedo, E., Rullan Rosanis, S., \& Villafuerte, L. (2016). Hierarchical capitalism in Latin America: Comparative Analysis with Other Economies. International Journal of Business and Economic Sciences Applied Research, 8(3), 69-82. https://hrcak.srce.hr/161613

Schneider, B. (1999). The desarrollista state in Brazil and Mexico. In M. Woo-Cumings (Ed.), The Developmental State. Cornell University Press.

Schneider, B. (2008). Economic liberalization and corporate governance: The resilience of business groups in Latin America. Comparative Politics, 40(4), 379-397. https://doi.org/10.5129/001041508X 12911362383237

Schneider, B. (2009). A comparative political economy of diversified business groups, or how states organize big business. Review of International Political Economy, 16(2), 178-201. https://doi.org/10.1 080/09692290802453713

Schneider, B. R. (2013). Hierarchical Capitalism in Latin America: Business, Labor, and the Challenges of Equitable Development. Cambridge University Press. https://doi.org/10.1017/CB09781107300446

Serna, M., \& Bottinelli, E. (2018). El poder fáctico de las élites empresariales en la política latinoamericana. CLACSO. 
Sheahan, J. (2002). Alternative models of capitalism in Latin America. In E. Huber (Ed.), Models of Capitalism. Lessons for Latin America. Penn State University Press.

Shipra. (2019). Book Review: José van Dijck, Thomas Poell and Martijn De Waal, The Platform Society: Public values in a connective world. Indian Journal of Human Development, 13(2), 235-38. ht tps://doi.org/10.1177/0973703019870883

Singh, N., \& Ovadia, J. (2018). The theory and practice of building developmental states in the Global South. Third World Quarterly, 39(6), 1033-1055. https://doi.org/10.1080/01436597.2018.145 5143

Singh, P. J. (2020). Breaking up Big Tech: Separation of its data, cloud and intelligence layers. (Working Paper No. 09). Data Governance Network. https://datagovernance.org/files/research/1595858876.pd $f$

Srnicek, N. (2016). Platform capitalism. Polity Press.

tecnopolítca. (2020, May 14). Data Commons Manifesto. May 14. https://tecnopolitica.net/en/content/ data-commons-manifesto

Torres Castro, C. M. (2016). Comparación de Factores que han Afectado la Regulación de Uber en Bogotá, Colombia y Ciudad de México, México [Civil Engineering Degree Project, Universidad de los Andes]. https://repositorio.uniandes.edu.co/bitstream/handle/1992/15139/u754541.pdf

U.N.C.T.A.D. (2019). Digital Economy Report 2019. Value Creation and Capture: Implications for Developing Countries[Report]. United Nations.

Vacano, M. (2017). Sharing economy' versus 'informal sector': Jakarta's motorbike taxi industry in turmoil. ANUAC, 6(2), 97-101. https://doi.org/10.7340/anuac2239-625X-3076

Valga Gutierrez, A. (2020). ¿Políticas para la economía del futuro? La economía colaborativa y las plataformas digitales en el Perú: Un análisis de la respuesta del Congreso de la República (2014-2019) [Faculty of Social Sciences, Pontificia Universidad Católica del Perú]. http://hdl.handle.net/20.500.1 $2404 / 16790$

van Dijck, J., Poell, T., \& Waal, M. (2018). The Platform Society: Public Values in a Connected World. Oxford University Press.

Vida. (2017). Anfitriones de Airbnb tienen que formalizarse: Mincomercio. El Tiempo. https://www.el tiempo.com/vida/viajar/anfitriones-de-airbnb-tienen-que-formalizarse-con-registro-nacional-de-tur ismo-117

Vizcarra, M., \& Villanueva, C. (2018). Oficio No 363-2018-PR Letter from the President of the Republic to Daniel Salavrry Villa, President of the Congress of the Republic. http://www.leyes.congreso.gob.pe/D ocumentos/2016_2021/Observacion_a_la_Autografa/OBAU0150520181228.pdf

Winter Etcheberry, G. (2019). Moción: Modifica la ley No 20.423, del Sistema Institucional para el Desarrollo del Turismo, y la ley No 19.537, sobre Copropiedad Inmobiliaria, para regular los servicios de alojamiento temporal ofrecidos a través de plataformas digitales. In 12978-02. http s://www.camara.cl/verDoc.aspx?prmTipo=SIAL\&prmID=50725\&formato=pdf 
Published by

IIIIII

I O Alexander von Humboldt

INSTITUTE FOR INTERNET

AND SOCIETY in cooperation with

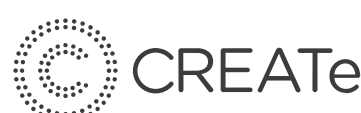

$\because::$ : : : :

Cnrs - internet

et societe

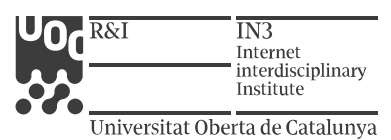

$\widehat{~ U N I V E R S I T Y ~ O F ~ T A R T U ~}$

III!! Johan Skytte Institute of Political Studies 